\title{
Determinants of Career Success: A Case Study of Male Teachers in Secondary Schools
}

\author{
SHAHRUL NIZAM SALAHUDIN ${ }^{1}$, HANI SUHAILA RAMLI ${ }^{2}$, MUHAMMAD HELMY ABD RAZAK ${ }^{3}$, \\ MUHAMMAD SAFIZAL ABDULLAH ${ }^{4}$, AHMAD MASUM $^{5}$ \\ ${ }^{1}$ Faculty of Technology Management \& Business, UNIVERSITI TUN HUSSEIN ONN, MALAYSIA. \\ ${ }^{2}$ Faculty of Business, MULTIMEDIA UNIVERSITY, MALAYSIA. E-mail: hani.ramli@mmu.edu.my \\ ${ }^{3}$ Faculty of Business, MULTIMEDIA UNIVERSITY, MALAYSIA. \\ ${ }^{4}$ School of Business, Innovation \& Technopreneurship, UNIVERSITI MALAYSIA PERLIS, MALAYSIA. \\ ${ }^{5}$ Faculty of Law \& Shariah, UNIVERSITI ISLAM SULTAN SHARIF ALI, BRUNEI.
}

\begin{abstract}
Malaysian secondary schools are facing a shortage of male teachers. Almost $70 \%$ of the teaching profession is dominated by female teachers. There is an obvious gap in the reason why teaching is not preferred by the male gender. This study intends to find the determinants of career success among male teachers with the hope of revealing the career success factors that are associated with male teachers. A survey was done among 140 male teachers in secondary schools in the state of Malacca, Malaysia. Results showed that 4out of 5 of the determinants factors are significantly explaining career success among the teachers (Emotional Intelligence, Person-Job-Fit, Career Adaptability \& Work-Life Balance) while one is unable to explain the career success of the teachers (Career Commitment). The findings enable policymakers to prioritize and draft better career development plans for the teachers that focus on issues about the recruitment of more emotional intelligence teachers, optimize person-job-fit and designing jobs that emphasize work-life balance.
\end{abstract}

Keywords: Teachers; Career Success Factors and Secondary School Education

JEL Classification: 015

Recibido: 23 de Noviembre de 2020

Aceptado: 1 de Abril de 2021 


\section{Introduction}

Malaysia's teaching profession is being dominated by the female gender. Only $30 \%$ of the teachers in Malaysia are male and the numbers are still showing no sign of improving even when the numbers of the pupil are on the rise every year (Ministry of Education Malaysia, 2018). There is a clear sign that the teaching profession is not being viewed as a fulfilling career for the male gender. This is also being strengthened by the fact that there is a significant $1 \%$ further decrease in the number of male teachers in 2017 if compared to 2016 (Ministry of Education Malaysia, 2018). Why is it that this career is not being preferred by the male gender? What could be the factors that hinder more male teachers being recruited into the teaching profession?

"Among teachers, the need for more men in the profession is often taken for granted, although many of them address this discussion critically" (Lahelma, 2000). In Malaysia, there is no specific drive or policies that had ever been undertaken by the government to increase the number of men choosing teaching as a profession. But is there a need for more male teachers? A study in Finland found out that there are no significant preferences when it comes to the pupils' views on male or female teachers (Lahelma, 2000). Nevertheless, this paper is not looking to find out why the teaching profession is not being preferred by the male gender but it is trying to explore what are the determinants in the career success of male teachers simple because it may lead to other researcher interests on the subject of gender and career success. The results could also provide some insights on what are the significant factors that lead to the career success of male teachers in the teaching profession.

Career success can be defined as desired positive career success results that are achieved from gained in work. (Sutin, Costa Jr., Miech \& Eaton, 2009). Career success is very important for every individual since it affects the individual in the sense of financial independence, maintain one's identity, being a role model to others and strengthen the confidence level of an individual. Besides that, the rising numbers of scholars and researchers focusing on the subject of career success results in a higher level of public interests where it shows that the standing of studies in career success is increasing along the years (Lirio, Lituchy, Monserrat, Olivas, Duffy, Fox, \& Santos, 2007).

\section{Literature Review: Career Success}

The two types of career success are objective and subjective. "Objective career success can be defined as the career satisfaction of an individual that is motivated from one's job title, serving as a landmark that measures their movement within the social environment by observing their positions and situations in works; and subjective career success describes the individual's personal feelings towards their career and which path they are moving on" (Arthur, Khapova, Widerom, 2005). Objective career success also known as extrinsic career success describes the individual's career success based on several factors which are the salary, increment of salary annually, social status, and job title (Kammeyer et al, 2008). In other words, objective CS is measured by the quality of performance by an individual and when they get promoted to a higher level of their work position which makes them a successful person. The most common indicators that are being used by several researchers in studying one's career success are the promotion and growth of salary whereby all of them can be easily collected and analyzed (Hall, 2002). Meanwhile, subjective CS is defined as the private evaluation and concerns on the person's career based on any determinants that have some possible value to them (Arthur, Khapova, Widerom, 2005). Career aspirations can be one of the possible values of one's opinion of career success. Different people value the factors of subjective CS differently, for example, an individual may take

their person-job fit as the most important in their career where the other may take the income stability and employment security as the most important in their career. It is very difficult to categorize people's orientation towards subjective career success by their occupation because there are no significant studies found to support this argument in career success. 


\subsection{Determinants of Career Success}

Although many researches had over the years associate factors that significantly affect career success, this study will focus only on the most prevalent ones which were used by most of the research related to career success. Among the subjective career success determinants chosen to be deployed in this study are work-life balance, person-job fit, emotional intelligence, social commitment, social capital and cognitive intelligence (Sutin, Costa Jr. Miech \& Eaton, 2009).

\subsubsection{Emotional Intelligence \& Career Success}

$\mathrm{El}$ is the ability of an individual in determining, accessing and controlling themselves and how their reactions towards the emotions shown by others (Meyer, Salovey, \& Caruso, 2008). According to MacCann, Newman, Joseph \& Roberts (2014); El is the "combination of behaviors, personal beliefs, attitudes, and motivation". Bar-On (2002) states that people with higher El are more capable of handling their work routines and demands. It also supported by Duran, Extremera \& Rey (2004) which can be supportive to reduce the level of negative career outcomes and boost employees' well-being. Thus, the awareness towards social conditions tends to be implemented by the people who have high $\mathrm{El}$ and they know how to react and adapt to the different situations that are being faced where this ability can lead to positive career outcomes. Additionally, Bar-On (2002) stated that people with higher emotional intelligence are more capable of encountering their work demands.

\subsubsection{Career Adaptability \& Career Success}

Hartung, Porfeli, \& Vondracek, (2008) says that occupational psychology is made up of several components and one of them is the career adaptability. Based on the previous researches, career adaptability is defined as a dimension that consists of the combination of one's behaviors, attitude, and competencies that plays an important role as the key tool to support the individuals in adapting their career success (Savickas, 2013). Also, career adaptability shows how an individual interacts with the working environment and their capability in handling tasks and challenges faced in their working environment. There is a positive relationship between CA and CS as it helps the individuals in forecasting the positive outcomes in their career orientation (Zacher, 2014). (Spurk et al., 2013) found out that there are also significant associations between CA and CS

\subsubsection{Career Commitment \& Career Success}

Career commitment is defined as the psychological relationship between motivation of an individual and their job where it drives them to give their full commitment to the chosen careers to obtain positive outcomes (Lee, Carswell \& Allen, 2000). Based on the definition, it extracts the meaning where there is a need for an individual to have a high career commitment because it is necessary towards the success in the individuals' professions. Studies found that there were positively significant influence between career commitment and subjective CS as well as positive career success (Sultana, Yousaf, Khan \& Saeed, 2016; Karavardar, 2014)

\subsubsection{Work-Life Balance \& Career Success}

The significance of work/life balance has chameleon qualities. It implies various things to various gatherings, and the significance frequently relies upon the setting of the discussion and the speaker's perspective (Lockwood, R.L, 2003). Work/life balance from the representative perspective is the problem of overseeing work commitments and individual/family obligations and Work/life balance from the business perspective: the test of making a strong organization culture where workers can concentrate on their employments while grinding away (SHRM, 2003). Studies propose that Work-Life balance is a huge supporter of how representatives see their occupations (Negrey,1984; Milkie, M. A. and Peltola, P, 1999; Tilly, C,1996). 


\subsubsection{Person-job fit \& Career Success}

Person-job fit is characterized as the connection between a individual's characteristics and their job characteristics and determines how well a person is suited with their working position (Kristof-Brown, Zimmerman \& Johnson, 2005). It is proven that person-job fit plays an important role in increasing an individual's level of job satisfaction and commitment towards the organization. As a result, it will influence the individual's subjective career success and reduce the turnover intention and it will encourage the individual to perform good behavior (Hoffman \& Woehr, 2006).

\subsection{Hypotheses Development}

Based on the relationships discovered in previous researches, this study proposed these hypotheses:

$\mathrm{H} 1$ : There is a significant association between El and CS of male teachers

$\mathrm{H} 2$ : There is a significant association between Career Adaptability and CS of male teachers

H3: There is a significant association between Career Commitment and CS of male teachers

$\mathrm{H} 4$ : There is a significant association between Work-Life Balance and CS of male teachers

H5: There is a significant association between Person Job Fit and Career Success of male teachers

H6: The determinants of CS affect the career success of male teachers significantly.

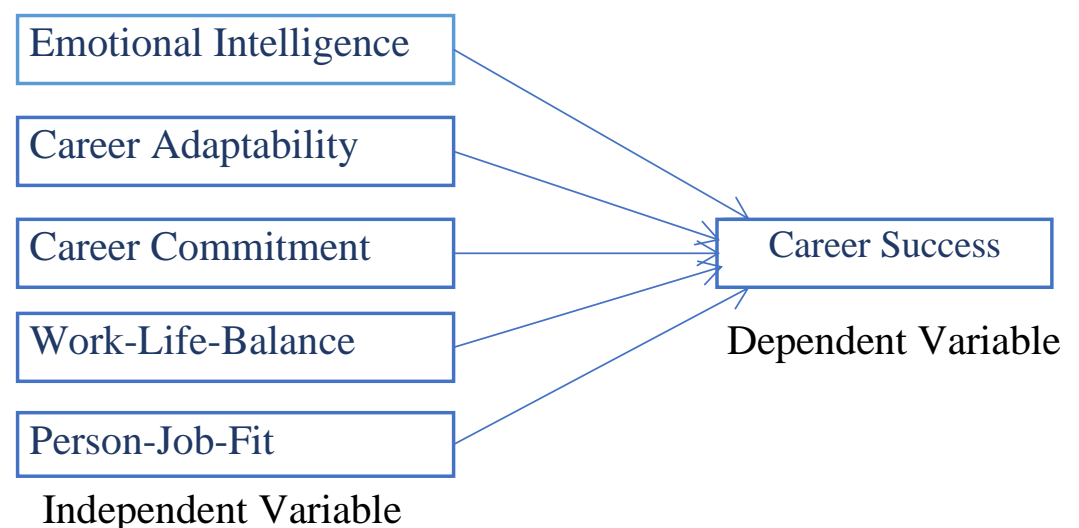

Figure 1: Research Framework: Determinants of Career Success (Model1)

\section{Methodology}

140 Male teachers were conveniently picked around schools in the state of Malacca and were asked to fill up a questionnaire that was adopted and adapted from different sources (Said, Rasdi, Samah, Silong \& Sulaiman, 2015; Aydin, 2016; Aryee, Chay \& Chew, 1994; Zacher, 2014 \& Zainal Nasurdin \& Hoo, 2011). The questionnaire was meant to measure the degree of each of the variables involved in this study (Career Success, Emotional intelligence, Career Commitment, Work-Life-Balance, Career Adaptability, Person-Job-Fit). The details of the questionnaire are depicted in table 1. Data gathered were subjected to Cronbach Alpha reliability analysis in which each of the variables tested recorded readings ranging from 0.765 to 0.942 . Table 1 depicts the results of the reliability test:

Table 1: Cronbach Alpha Test

\begin{tabular}{|c|c|c|c|}
\hline Variables & Number of Items & Cronbach's Alpha & Level of Reliability \\
\hline Subjective Career Success (SC) & 8 & 0.935 & Excellent \\
\hline Emotional Intelligence (EI) & 4 & 0.895 & Very good \\
\hline Career Adaptability (CA) & 4 & 0.765 & Good \\
\hline Career Commitment (CC) & 7 & 0.806 & Eery good \\
\hline Person-Job Fit (PJF) & 4 & 0.916 & Excellent \\
\hline Work-Life Balance (WLB) & 5 & 0.942 & \\
\hline
\end{tabular}




\section{Results \& Findings}

\subsection{Descriptive Statistics}

The total sample used in this study is 140 Male teachers between the ages of $30-45$ years old $(80 \%)$ Whereby the remaining teacher is from the ages of $21-29(10 \%)$ and 51 above $(10 \%)$. Over $80 \%$ of the teachers are married. Malay teachers consist of $60 \%$, Chinese teachers consist of $17 \%$ and the rest are Indian teachers (23\%). As far as the educational qualifications, most of the teachers possess a Bachelor's degree (87\%) and it is worth mentioning that more than $70 \%$ of the teachers took 5 years or more to achieve their current job grades. Mean values for all the variables range from 2.88 to 4.30 whereby the standard deviations

Table 2: Mean \& Standard Deviations

\begin{tabular}{|c|c|c|c|}
\hline Variables & $\mathbf{N}$ & Mean & Std. Deviation \\
\hline Subjective Career Success & 140 & 4.1518 & 0.74153 \\
\hline Emotional Intelligence & 140 & 4.2071 & 0.70898 \\
\hline Career Adaptability & 140 & 4.0786 & 0.82567 \\
\hline Career Commitment & 140 & 3.6439 & 0.63853 \\
\hline Person-Job Fit & 140 & 4.3054 & 0.71537 \\
\hline Work-Life Balance & 140 & 2.8886 & 1.13727 \\
\hline
\end{tabular}

\subsection{Hypotheses Testing}

All of the hypotheses are subjected to two types of testing which are the Pearson Correlation (to test the associations between the independent and the dependant variables) and a multiple regression analysis (to test the effects of the independent variables on the dependant variable). The multiple regression analysis is also undertaken to propose a linear regression model that could explain the variations in the dependant variable.

Table 3: Pearson Correlation Analysis

\begin{tabular}{|c|c|c|c|c|c|c|}
\hline Variables & SC & EI & CA & CC & PJF & WLB \\
\hline Career Success (CS) & 1 & & & & & \\
\hline Emotional Intelligence (EI) & $0.771^{* *}$ & 1 & & & & \\
\hline Career Adaptability (CA) & $0.459^{* *}$ & $0.416^{* *}$ & 1 & & & \\
\hline Career Commitment (CC) & -0.156 & $-0.172^{*}$ & -0.095 & 1 & & \\
\hline Person-Job-Fit (PJF) & $0.774^{* *}$ & $0.765^{* *}$ & $0.358^{* *}$ & -0.102 & 1 & \\
\hline Work-Life Balance (WLB) & $-0.693^{* *}$ & $-0.585^{* *}$ & $-0.533^{* *}$ & 0.077 & $-0.561^{* *}$ & 1 \\
\hline
\end{tabular}

\subsubsection{Hypotheses 1-5}

Pearson Correlations has been used to test hypotheses 1-5 whereby the test is used to identify the correlations/associations of the tested variables. The dependent variable is the Subjective CS (SC) and the independent variables are emotional intelligence (EI), career adaptability (CA), career commitment (CC), person-job fit (PJF) and work-life balance (WLB). Based on table 3, the correlation value for emotional intelligence (EI) is 0.771 , career adaptability (CA) 0.459 , career commitment (CC) is -0.156 , person-job fit (PJF) is 0.774 and work-life balance (WLB) is -0.693 . The results also showed that emotional intelligence and person-job fit has the highest value of positive associations with career success ( 0.771 and 0.774 ) while career adaptability has a weaker association with career success (0.459). As for work-life balance, it has a negative association value of 0.693 . Meanwhile only one of the variables doesn't have a significant association with career success (Career commitment; -0.156). Note that the positive associations meant that increase in one variable will be followed by an increase in the associated variable while negative associations meant that an increase in the value of one variable will be followed by a decrease in value for the associated variable.

The results depicted in Table 3 show that 4 out of the hypotheses where accepted in which emotional intelligence, career adaptability, Person-Job fit, and Work-Life balance have significant 
associations with career success. Therefore $\mathrm{H} 1, \mathrm{H} 2, \mathrm{H} 4$, and $\mathrm{H} 5$ are fully accepted. Meanwhile, since Career commitment does not relate to career success, $\mathrm{H} 3$ was rejected.

\subsubsection{Hypotheses 6}

Multiple regression analysis was used to capture the effect that the independent variables have (Emotional Intelligence, Career Adaptability, Career Commitment, Person-Job-Fit \& Work-Life Balance) on the dependant variable (Career Success).

Table 4. Model Summary: The Effects of Determinants of Career Success on Career Success of Male Teachers

\begin{tabular}{|c|c|c|c|c|}
\hline $\mathbf{R}$ & R Square & Adjusted R Square & Std Error of the Estimates & Durbin-Watson \\
\hline \hline $0.859 \mathrm{a}$ & 0.737 & 0.728 & 0.38701 & 1.555 \\
\hline
\end{tabular}

a. Predictors: (Constant), Emotional intelligence, career adaptability, career commitment, person-job fit, and work-life balance.

b. Dependent Variable: Subjective career success.

The table above shows the Multiple Linear Regression summary for the study. The R square value implies to the percentage of the dependent variable supported by the independent variable. Hence, for this study, the $\mathrm{R}$ square value is 0.737 which is the percentage of variation in the dependent variable supported by the independent variables. It indicates that $73.7 \%$ of the variation in subjective CS (SC) is explained by the independent variables which are emotional intelligence (EI), career adaptability (CA), career commitment (CC), person-job fit (PJF) and work-life balance (WLB).

Table 5. ANOVA Table

\begin{tabular}{|c|c|c|c|c|c|}
\hline & Sum of Squares & df & Mean Squares & F & Sig \\
\hline Regression & 56.361 & 5 & 11.272 & 75.261 & $0.000^{\mathrm{b}}$ \\
\hline Residual & 20.07 & 134 & 0.15 & & \\
\hline Total & 76.431 & 139 & & & \\
\hline
\end{tabular}

The ANOVA results presented in table 5 shows that the $F$-value is 75.261 and it indicates that there is a model fit. Besides that, the $p$-value is 0.000 which is less than 0.05 . Therefore, it shows that the independent variables of emotional intelligence (EI), career adaptability (CA), career commitment (CC), person-job fit (PJF) and work-life balance (WLB) make a significant contribution to subjective CS.

Table 6 Summary of Regression Analysis

\begin{tabular}{|c|c|c|c|c|c|c|}
\hline & \multicolumn{7}{|c|}{ Dependent variable (Career Success) } \\
\hline Independent Variable & Constant(B) & R Value & R Square & F Statistics & B (Unstandardized) & Significant \\
\hline Constant & 1.746 & $0.859 a$ & 0.737 & 75.261 & & $0.000^{*}$ \\
\hline Emotional Intelligence & & & & & 0.312 & \\
\hline Career Adaptability & & & & & 0.044 & \\
\hline Career Commitment & & & & & -0.047 & \\
\hline Person - Job Fit & & & & & 0.377 & \\
\hline Work-Life Balance & & & & & -0.186 & \\
\hline
\end{tabular}

Table 6 depicts the linear model of Career Success. The linear model based on the results is:

Career success $=1.746+0.312$ (Emotional Intelligence) +0.044 (Career Adaptability) -0.047 (Career Commitment) +0.377 (Person-Job Fit) -0.186 (Work-Life Balance) .

The sequence of results depicted earlier confirms the acceptance of Hypotheses 6 in which the determinants of career success affect career success among the male teachers.

\section{Conclusion and Discussion.}

The results shed light on understanding of the factors that are related to the career success of male teachers. The results showed that although it was clear in previous studies that all of the selected factors have significant associations with the independent variable, it wasn't all true concerning the results gathered from this study. The results depicted that only 4 out of the 5 factors have significant associations with the dependent variables whereby one of the determinants did not have significant 
associations. The factors that were highly correlated with career success in this context were emotional intelligence, person-job fit, and work-life balance. Meanwhile, career adaptability has a mediocre relationship with CS and career commitment has no significant relationship altogether. This study found out that the relationship between emotional intelligence and CS is considered quite strong and is consistent with results of many previous studies which confirms that emotional intelligence has a significant relationship with CS (Boyatzis, 1982, 2009; Kotter, 1982; Luthans et al., 1988; Thornton and Byham, 1982; Druskat et al., 2005). This means that people of higher degrees of emotional intelligence tend to do well in their careers and are most likely to succeed in their careers. Another determinant of career success is career adaptability in which the results found out that career adaptability has a significant relationship with CS. The results are also in line with results gathered from previous studies (Zacher, 2014; leva, 2014) whereby most of the studies suggested that career adaptability as a good determinant factor of career success. As for Person Job fit, the results gathered are consistent with many previous studies whereby person-job fit relates to career success (Bretz \& Judge, 1994; Kristof, 1996; Caldwell \& O'Reilly, 1990; Lauver \& Kristof-Brown, 2001). This means that the person-job fit is one of the significant determinants of one's career success. What this means is that people that are better fitted in their jobs are most likely to achieve career success. Another variable that was tested was work-life balance and the results also confirm the findings of previous studies (Greenhaus, Collins \& Shaaw, 2003) which state that the two variables are related. This implies that people with a good sense of work-life balance will be more likely to achieve success in their careers in comparison with people who do not have favorable work-life balance. There is only one variable that was tested in this study which doesn't have significant relations with career success. That variable is career commitment. Although many studies suggested that career commitment as having associations with career success, this study found otherwise. Nevertheless, some researches found no significant relationship between the two variables (Poon, J. 2014).

Finally, as far as whether the determinants of career success suggested will be able to predict career success, the multiple regression analysis results confirm that there is a model fit and therefore hypotheses 6 is accepted. The results showed that $73 \%$ of the variance in career success can be explained by the model. What this means is that the degree of emotional intelligence, career adaptability, career commitment, person-job fit, and work-life balance have a significant effect on the career success of the teachers. The results of this study will be able to help policymakers on developing policies that take into consideration the determinants as were suggested. This is important to further help enhance the abilities of the teachers to pursue career success in their career development. The policymakers now have empirical evidence that some factors have a direct effect on the career success of male teachers and can use this as justifications on improving policies that are governing career development of the teachers here in Malaysia. Considerations such as Career adaptability, Person job fit and emotional intelligence can be used as criteria in recruiting new teachers and for the teachers that are already in service, work-life balance can be considered seriously as far as the teachers' workload is a concern.

\section{References}

1. Arthur, M. B., Khapova, S. N., \& Wilderom, C. P. M. (2005). Career Success in a boundaryless. Journal of Organizational Behavior, 26(2), 177-202.

2. Bar-On, R. (2002). EQ-I: Bar-On emotional quotient inventory technical manual. Toronto, Canada: Multi-Health Systems.

3. Boyatzis, R.E. (1982). The competent manager: a model for effective performance. London: Wiley.

4. Bretz, R.D. and Judge, T.A. (1994) Person-Organization Fit and the Theory of Work Adjustment: Implications for Satisfaction, Tenure, and Career Success. Journal of Vocational Behavior, 44, 32-54

5. C. Negrey. (1984) "Gender, Time \& Reduced Work" Albany, NY. State University of New York Press.

6. Caldwell, D. F., \& O'Reilly, C. A. III. (1990). Measuring person-job fit with a profile-comparison process. Journal of Applied Psychology, 75(6), 648-657 
7. Druskat, V., Mount, G., and Sala, F. (Eds.). (2005). Emotional Intelligence and Work Performance. Mahwah, NJ: Lawrence Erlbaum.

8. Durán A., Extremera N., Rey L. Self-reported emotional intelligence, burnout and engagement among staff in services for people with intellectual disabilities. Psychol. Rep. 2004;95:386-390

9. Elina Lahelma (2000) Lack of male teachers: a problem for students or teachers?, Pedagogy, Culture and Society, 8:2, 173-186

10.Greenhaus, J.H., Collins, K.M. and Shaw, J.D. (2003) The Relation between Work-Family Balance and Quality of Life. Journal of Vocational Behavior, 63, 510-531

11. Hall, D. T. (2002). Careers In and Out of Organizations. SAGE Publications.

12.Hoffman, B. J., \& Woehr, D. J. (2006). A quantitative review of the relationship between personorganization fit and behavioral outcomes. Journal of Vocational Behavior, 68(3), 389-399.

13.leva, U; Antanas, K; Birote, P. \& Audrone, L (2014) "Career adaptability in Lithuania: A test of psychometric properties and a theoretical model" Journal of Vocational Behavior. Vol 85 No. 3 pp 433-442.

14.Kammeyer-Mueller, J. D., Judge, T. A., \& Piccolo, R. F. (2008). Self-esteem and extrinsic career success: Test of a dynamic model. Applied Psychology, 57(2), 204-224.

15.Karavardar, G. (2014). Career Commitment, Subjective Career Success and Career Satisfaction in the Context of Hazelnut Processing Industry in Giresun/Turkey. International Journal of Business and Management, 9(6), 98-105.

16.Kotter, J. P. (1982). The General Managers. New York: Free Press.

17.Kristof, A. L. (1996). Person-organization fit: An integrative review of its conceptualizations, measurements, and implications. Personnel Psychology, 49, 1-49

18. Kristof-Brown, A. L., Zimmerman, R. D., and Johnson, E. C. 2005. "Consequences of Individual's Fit at Work" Personnel Psychology, (58), pp. 281-342.

19.Lahelma (2000) Lack of male teachers: a problem for students or teachers?, Pedagogy, Culture and Society, 8:2, 173-186

20.Lauver, K. J., \& Kristof-Brown, A. (2001). Distinguishing between employees' perceptions of person-job and person--organization fit. Journal of Vocational Behavior, 59(3), 454-470

21.Lee K., Carswell J.J., Allen N. (2000) A meta-analytic review of occupational commitment: Relations with person- and work-related variables. J. Appl. Psychol.; 85:799-811

22.Lirio, P., Lituchy, T. R., Monserrat, S. I., Olivas-Lujan, M. R., Duffy, J. A., Fox, S. Santos, (2007). Exploring career-life success and family social support of successful women in Canada, Argentina and Mexico. Career Development International, 12, 28-50

23.Lockwood, R. L. (2003). Work/Life Balance; Challenges \& Solutions; SHRM Knowledge Center. Retrieved from http://shrm.org/ressearch/quaterly/0302worklife_essay.asp.

24.Luthans, F., Hodgetts, R. M., \& Rosen krantz, S. A. (1988). Real managers. Cambridge, MA: Ballinger.

25.MacCann, C., Joseph, D. L., Newman, D. A., \& Roberts, R. D. (2014). Emotional intelligence is a second-stratum factor of intelligence: Evidence from hierarchical and bifactor models. Emotion, 14(2), 358-374.

26. Mayer, J. D., Salovey, P., \& Caruso, D. R. (2008). Emotional intelligence: new ability or eclectic traits? American Psychologist, 63, 503-517

27.Milkie, M. A. \& Peltola, P. A. (1999). Playing all the roles: Gender and the work-family balancing act. Journal of Marriage and the Family, 61, 476-490.

28. Malaysia Educational Statistics, Ministry of Education Malaysia. (2018).

29.Moss. P; Tilly. C. (1996) "Soft" Skills and Race: An Investigation of Black Men's Employment Problems", Journal of Work \& Occupations, Volume: 23 issue: 3, page(s): 252-276.

30.Negrey, C. (1984). Gender, time, and reduced work. Albany: State University of New York Press.

31.Poon, J. (2014), "Career commitment and career success: moderating role of emotion perception", Career Development International, Vol. 9 No. 4, pp. 374-390.

32.Porfeli, E. J., Hartung, P. J., \& Vondracek, F. W. (2008). Children's vocational development: A research rationale. The Career Development Quarterly, 57(1), 25-37. 
33.Presser, H. B. (1995). Job, family and gender: Determinants of nonstandard work schedules among employed Americans in 1991. Demography, 32, 577-95

34.Savickas M. L. (2013). The 2012 Leona Tyler Award address constructing careers - actors, agents, and authors. Counsel. Psychol. 41, 648-662

35.Spurk, D., Volmer, J., Hagmaier, T., \& Kauffeld, S. (2013). Why are proactive people more successful in their careers? The role of career adaptability in explaining multiple career success criteria. Personality Traits: Causes, Conceptualizations, and Consequences, pp. 27-48

36.Sultana, R., Yousaf, A., Khan, I. and Saeed, A. (2016), "Probing the interactive effects of career commitment and emotional intelligence on perceived objective/subjective career success", Personnel Review, Vol. 45 No. 4, pp. 724-742

37.Sutin, A. R., Costa, P. T., Jr, Miech, R., \& Eaton, W. W. (2009). Personality and Career Success: Concurrent and Longitudinal Relations. European journal of personality, 23(2), 71-84. doi:10.1002/per.704

38.Thornton, G.C., \& Byham, W.C. (1982). Assessment centers and managerial performance. New York: Academic Press

39.Tilly, C. (1996). Half a job: Bad and good part-time jobs in a changing labor market. Philadelphia: Temple University Press

40.Zacher, H. (2014). "Career adaptability predicts subjective career success above and beyond personality traits and core self-evaluations". Journal of Vocational Behavior. Vol 84 No. 1 pp 21-30. 